\title{
Vibrio parahaemolyticus: a review on the pathogenesis, prevalence, and advance molecular identification techniques
}

\author{
Vengadesh Letchumanan ${ }^{1,2}$, Kok-Gan Chan ${ }^{2}$ and Learn-Han Lee ${ }^{1}$ * \\ 1 Jeffrey Cheah School of Medicine and Health Sciences, Monash University, Bandar Sunway, Malaysia \\ ${ }^{2}$ Division of Genetics and Molecular Biology, Institute of Biological Sciences, Faculty of Science, University of Malaya, Kuala Lumpur, Malaysia
}

\section{Edited by:}

Dongsheng Zhou, Beijing Institute of Microbiology and Epidemiology, China

Reviewed by:

Adrian Canizalez-Roman, Autonomous University of Sinaloa, Mexico

Lingling Zhang, University of Texas

Southwestern Medical Center at

Dallas, USA

Pendru Raghunath, Dr. VRK Women's

Medical College, India

\section{${ }^{*}$ Correspondence}

Learn-Han Lee, Jeffrey Cheah School of Medicine and Health Sciences, Monash University, 46150 Bandar Sunway, Selangor Darul Ehsan,

Malaysia

e-mail: lee.learn.han@monash.edu;

leelearnhan@yahoo.com
Vibrio parahaemolyticus is a Gram-negative halophilic bacterium that is found in estuarine, marine and coastal environments. V. parahaemolyticus is the leading causal agent of human acute gastroenteritis following the consumption of raw, undercooked, or mishandled marine products. In rare cases, $V$. parahaemolyticus causes wound infection, ear infection or septicaemia in individuals with pre-existing medical conditions. $V$. parahaemolyticus has two hemolysins virulence factors that are thermostable direct hemolysin (tdh)-a poreforming protein that contributes to the invasiveness of the bacterium in humans, and TDHrelated hemolysin (trh), which plays a similar role as $t d h$ in the disease pathogenesis. In addition, the bacterium is also encodes for adhesions and type III secretion systems (T3SS1 and T3SS2) to ensure its survival in the environment. This review aims at discussing the $V$. parahaemolyticus growth and characteristics, pathogenesis, prevalence and advances in molecular identification techniques.

Keywords: Vibrio parahaemolyticus, food borne, prevalence, pathogenesis, virulence factors, clinical manifestation, molecular techniques

\section{INTRODUCTION}

The presence of pathogenic bacteria in the worldwide marine environment raises concerns of human on food safety due to the latter potentially causing disease outbreaks depending on the environmental conditions (Ceccarelli et al., 2013). A good example is Vibrio parahaemolyticus, a member of Vibrio species from the Vibrionaceae family. V. parahaemolyticus is a Gram-negative halophilic bacterium that is widely disseminated in estuarine, marine and coastal surroundings (Su and Liu, 2007; Nelapati et al., 2012; Ceccarelli etal., 2013; Zhang and Orth, 2013). $V$. parahaemolyticus is usually found in a free-swimming state; with its motility conferred by a single polar flagellum affixed to inert and animate surfaces including zooplankton, fish, shellfish or any suspended matter underwater (Gode-Potratz et al., 2011). The classification of $V$. parahaemolyticus depends on the antigenic properties of the somatic $(\mathrm{O})$ and capsular $(\mathrm{K})$ antigen produced in various environmental condition (Nair et al., 2007).

Vibrio parahaemolyticus was first discovered by Tsunesaburo Fujino in 1950 as a causative agent of food borne disease following a large outbreak in Japan which recorded 272 illnesses with 20 deaths after consumption of shirasu. (Fujino et al., 1953). Virulent V. parahaemolyticus strains are transmitted by consumption of raw or undercooked seafood causing acute gastroenteritis (Newton et al., 2012; Zarei et al., 2012). In rare cases, V. parahaemolyticus causes wound infection, ear infection or septicaemia that may be life-threatening to individuals with pre-existing medical conditions (Zhang and Orth, 2013). Since its discovery, V. parahaemolyticus has been found to be responsible for $20-30 \%$ of food poisoning cases in Japan and seafood borne diseases in many Asian countries (Alam et al., 2002). V. parahaemolyticus was also recognized as the leading cause of human gastroenteritis associated with seafood consumption in the United States (Kaysner and DePaola, 2001; Newton et al., 2012).

The worldwide prevalence of $V$. parahaemolyticus gastroenteritis cases stresses the need for understanding of the virulence factors involved and their effects on humans. This article aims to discuss on V. parahaemolyticus as an emerging pathogen associated with seafood consumption and its effects to human in terms of pathogenesis, prevalence and the advances in molecular identification techniques used to identify $V$. parahaemolyticus.

\section{PATHOGENESIS OF Vibrio parahaemolyticus}

Vibrio parahaemolyticus strains have a number of different virulence factors including adhesins, thermostable direct hemolysin $(t d h)$ and TDH related hemolysin (trh) as well as two type III secretion systems, T3SS1 and T3SS2 (Makino et al., 2003). V.parahaemolyticus strains are encoded with T3SS1 to ensure its survival in the environment (Paranipye et al., 2012). The T3SS1 have a number of virulence factors that cause lysis of an infected host cell and allow for the release of important nutrients (Burdette et al., 2008). In addition, some $V$. parahaemolyticus strains gain a T3SS2, and $t d h$ and TDH related hemolysin ( $t r h)$ genes which lead to a number of strains with different degrees of pathogenicity. Besides T3SSs and TDH genes, V. parahaemolyticus have two different types of flagella with distinct functions for swimming 
and swarming, as well as the ability to produce a capsule. Both these factors are likely to help in the strains survival in the environment and also in colonization of a human host (Broberg et al., 2011).

\section{ADHESION TO HOST CELLS}

The most important step in bacterial pathogenesis is initial host cell binding. During infection, bacterial adhesion factors are present at the bacterial surface to form contact with host cell for secretion of effectors and toxin proteins. MAM7 (Multivalent Adhesion Molecule 7) is a novel adhesion which is conserved in many Gram-negative bacteria. MAM7 consists of a hydrophobic stretch of 44 amino acids at its $\mathrm{N}$ terminus, which is required for correct localization and outer membrane anchoring of the protein. MAM7 also contains seven mammalian cell entry (mce) domains (Zhang and Orth, 2013). MAM7 is constitutively expressed, enabling Gram-negative pathogens to establish immediate contact with host cells upon their first encounter, which in turn can lead to up-regulation of other pathogen-specific or host cell-specific adhesion and virulence factors (Krachler and Orth, 2011).

In the process, MAM7 will bind to both fibronectin and phosphatidic acid, and if either of these substrates is blocked, it could prevent adhesion of MAM7 to host cells. Heterologous expression of MAM7 is sufficient for attachment of a non-pathogenic Escherichia coli strain to host cells. This could in turn block attachment and attenuate cytotoxicity of $V$. parahaemolyticus or any other MAM7-expressing Gram-negative pathogens. In addition, MAM7 is necessary for initial host binding during infection and for T3SS-mediated cell death in some cell types. These insight on MAM7 provide a new perspective on bacterial and host cell interactions (Krachler et al., 2011). Furthermore, the discovery of MAM7 led to new research investigating this molecules potential as a therapeutic agent for many Gram-negative bacteria including V. parahaemolyticus (Krachler et al., 2012).

\section{TOXINS}

Outbreaks of $V$. parahaemolyticus illness have increased. This is particularly found in countries with high levels of seafood consumption where $V$. parahaemolyticus causes over half of all food-poisoning outbreaks of bacterial origin (Daniels et al., 2000a). The $t d h$ and TDH-related hemolysin (trh) are the two virulence factors associated with $V$. parahaemolyticus hemolysis and cytotoxicity activity in the host cell (Broberg et al., 2011; Zheng et al., 2014). V. parahaemolyticus bacteria are extensively present in marine and estuarine environments but not all strains of this bacterium are considered pathogenic (Velazquez-Roman et al., 2012). The strains isolated from environmental samples usually lack the pathogenic genes $t d h$ and/or $t r h$ which cause illnesses to humans and marine animals (Deepanjali et al., 2005; Canizalez-Roman et al., 2011; Gutierrez West et al., 2013). Nevertheless, studies from U.S., Europe and Asia have reported around $0-6 \%$ of the environmental samples analyzed to be positive for the presence of $V$. parahaemolyticus strains with $t d h$ gene and/or trh genes (Kaysner et al., 1990; DePaola et al., 2000; Vuddhakul et al., 2000; Wong et al., 2000a; Alam et al., 2002; Hervio-Heath et al., 2002).
Commonly, all the clinical $V$. parahaemolyticus strains isolated from humans with gastroenteritis are differentiated from the environmental strains based on the strains ability to produce $t d h$ which can lyse red blood cells on Wagatsuma blood agar. This hemolytic activity on Wagatsuma agar is known as Kanagawa phenomenon (Nishibuchi et al., 1989; Alipour et al., 2014). Only $1-2 \%$ of the environmental samples is reported to be KP-positive and the rest are categorized as KP-negative strains (Nishibuchi and Kaper, 1995; Alipour et al., 2014). Molecular epidemiological studies report that Vibrio parahaemolyticus KP-negative strains did not feature $t d h$ gene characteristic but produce a trh gene. A study has reported the isolation of a KP-negative $V$. parahaemolyticus strain that produces trh gene from an outbreak of gastroenteritis in the republic of Maldives in 1985 (Qadri et al., 2005). The trh gene plays a role similar to $t d h$ gene in the pathogenesis of $V$. parahaemolyticus and is therefore considered a virulence factor of $V$. parahaemolyticus (Nelapati et al., 2012).

\section{TYPE III SECRETION SYSTEMS OF Vibrio parahaemloyticus}

Type III secretion systems are needle-like bacterial machinery used to inject bacterial protein effectors directly into the membrane and cytoplasm of eukaryotic cells without encountering with the extracellular environment (Cornelis, 2006). T3SSs is made up of 20-30 proteins with a secretion apparatus consisting of a basal body that spans the inner and outer bacterial membranes, a needle that is polymerized and extended into extracellular space, and a translocon pore that is inserted into the eukaryotic cell membrane (Izore et al., 2011). Some secretion apparatus proteins have homology to flagellar export proteins, with core transmembrane proteins showing the highest level of conservation (Marlovits and Stebbins, 2010). The common targets of T3SS effectors include the actin cytoskeleton, innate immune signaling, and autophagy. Depending on the pathogens needs, the systems can be either up regulated or down regulated (Broberg et al., 2011).

\section{T3SS1}

The T3SS1 is present in all environmental and clinical V. parahaemolyticus strains (Paranjpye et al., 2012). This system is similar to Yersiniaysc T3SS in terms of the number of genes, its gene identity and the characteristic of being induced by increasing temperature or decreasing the calcium concentration (Ono et al., 2006; Zhang and Orth, 2013). The T3SS1 system is regulated by three interacting proteins (ExsC, ExsD, and ExsE) that control the activity of the master transcriptional regulator ExsA, a member of AraC family of transcription activators. Under non-inducing conditions, ExsA is bound to ExsD and rendered inactive, while ExsC, an anti-anti-activator of the system, is bound to ExsE. Under inducing conditions, when ExsE is secreted, ExsC is released and binds to ExsD which allows the release of ExsA and activates the transcription of T3SS1 genes (Zhou et al., 2010).

During tissue cell infection, T3SS1 initiates a series of events that involves autophagy, membrane blebbing, cell rounding, and lastly cell lysis. This entire reproducible series of events is carried out by three main effectors from T3SS1 gene including VopQ (VP1680), VPA0450, and VopS (VP1686). VopQ is induced by Pi3-kinase independent autophagy upon infection with POR3 or transfection of VopQ into Hela cells and prevents 
phagocytosis of the infecting bacteria (Sreelatha et al., 2013). In the event the VopQ is absent, infected macrophages are able to phagocytose V. parahaemolyticus and induce apoptosis. Thus, sequestering membrane resources by inducing autophagy is proposed to antagonize the ability of host cells to phagocytose $V$. parahaemolyticus.

VPA0450 is an inositol polyphosphate-5-phosphatase that hydrolyzes the D5 phosphate from phosphatidylinositol-4,5bisphosphate $[\mathrm{PI}(4,5) \mathrm{P} 2]$ in the plasma membrane (Broberg et al., 2010). It destabilizes the cell by detachment of the plasma membrane from the actin cytoskeleton, which leads to blebbing of plasma membrane and allows rapid lysis of the host cell (Broberg et al., 2010; Zhang and Orth, 2013). The third effector is VopS that targets the actin cytoskeleton by AMPylating Rho-family GTpase. It is responsible for the collapse of actin cytoskeleton which leads to cell rounding and shrinkage (Broberg et al., 2010; Ceccarelli et al., 2013). The Fic domain within VopS mediates the direct transfer of adenosine monophosphate from ATP to the switch 1 region of these small Gproteins, which prevents their binding to downstream effectors. This blocks the signaling cascade regulating the actin cytoskeleton and lead to its collapse (Zhou et al., 2010).

\section{T3SS2}

The T3SS2 encoded on a pathogenicity island on chromosome 2 is found in clinical isolates and is associated with pandemic V. parahaemolyticus strains (Paranjpye etal., 2012). T3SS2 is different from T3SS1, but has closest homology to the Hrp1 system found in Pseudomonas syringae (Park et al., 2004; Cornelis, 2006). In a rabbit ileal loop model, T3SS2 effectors are translocated into host cells causing cytotoxicity of colon epithelial and enterotoxicity within the host (Park et al., 2004). T3SS2 is closely associated with pathogenicity island (VPAI-7) and flanked by two $t d h$ genes (Zhang et al., 2012). The effectors of T3SS2 include VopC (VPA1321), VopT (VPA1327), VopA/P (VPA1346), and VopL (VPA1370).

VopC (VPA1321) has homologies to cytotoxic necrotizing factor 1 (CNF1), an exotoxin that is described in pathogenic E. coli strains. CNF1 activates Rho, Rac, and Cdc42 by deamidating a glutamine residue in the switch 2 region of each enzyme and preventing hydrolysis of GTP. This induces changes in the actin cytoskeleton and facilitates $V$. parahaemolyticus entry into nonphagocytic host cells (Zhang et al., 2012). The second effector is VopT (VPA1327), an ADP ribosyltransferase domain of the $P$. aeruginosa effectors ExoS and ExoT, which is able to modify the small GTPase Ras (Kodama et al., 2007). The VopT gene's is activity is partially responsible for the cytotoxicity seen during infection of Caco-2 monolayers with $V$. parahaemolyticus (Kodama et al., 2007).

VopA or also known as VopP is categorized as a YopJ homolog that blocks activation of the MAPK signaling pathway by acetylating a conserved serine, threonine, and lysine residue on MAPKKs. This prevents the phosphorylation and activation of the MAPK pathway, which prevents the induction of cytokines (Trosky et al., 2004). The activity of VopA/P could possibly be partially redundant with VopT as both block the activation of the ERK/MPK pathway (Broberg et al., 2011). The VopL (VPA1370) is a protein containing three Wiskott-Aldrich homology 2 (WH2) domains. This effector is responsible for the strong actin filament nucleation which is observed in host cell (Namgoong et al., 2011).

\section{TYPE VI SECRETION SYSTEMS (T6SS1 AND T6SS2)}

The type VI secretion systems, T6SS1 (VP1386-VP1420) and T6SS2 (VPA1030-VPA1043) are located on chromosome 1 and 2 respectively on V. parahaemolyticus RIMD 2210633 (Boyd et al., 2008; Izutsu etal., 2008). Preliminary data suggested that the T6SS2 is an adhesion and not involved in cytotoxicity (Yu et al., 2012). Since T6SS2 and T3SS2 systems co-exist, it is suggested that both systems might cooperate during an infection on host. T6SS2 takes the first step of infection as a role of adhesion where else T3SS2 exports effectors by inducing enterocytotoxicity (Park et al., 2004; Yu et al., 2012). It is reported that T6SS gene was used as a virulence marker to differentiate pandemic and non-pandemic strains isolated in Japan. The T6SS gene was present in all pandemic strains, whereas majority of the non-pandemic strains had a partial set of T6SS genes (Ceccarelli et al., 2013). In addition, researchers have reported that T6SS1 is most active under warm marine-like conditions, while T6SS2 is active under low salt conditions and that surface sensing and quorum sensing differentially regulate both systems (Salomon et al., 2013).

\section{PANDEMIC CLONE OF Vibrio parahaemolyticus}

Gastroenteritis due to V. parahaemolyticus occurs as sporadic cases caused by different serotypes. The epidemiology of this bacteria changed with the emergence of pandemic clone of 03:K6 serotype in Kolkata, India in year 1996 (Bisha et al., 2012). Since then, this 03:K6 strains have been involved in many food borne outbreaks in Asian countries (Matsumoto etal., 2000), United States and worldwide. Currently there are more than 20 serovariants including 03:K6, 04:K68, 01:K25, and 01:KUT (Nair et al., 2007).

The clinical isolates of pandemic and non-pandemic $V$. parahaemolyticus showed the presence of a $24 \mathrm{~kb}$ region which is known as $V$. parahaemolyticus island-1 (Vp-PAI-1) in 03;K6. Further molecular analysis on the other genomic islands demonstrated the presence of Vp-PAI-4, Vp-PAI-5, and Vp-PAI-6 in the pandemic strains (Hurley et al., 2006). The Vp-PAI-1 is suggested to be one of the markers of pandemicity owing to the presence of a virulence gene (Nishioka et al., 2008). The isolates in the pandemic group carried $t d h$ gene but not trh gene, orf8, Vp-PAI-1, Vp-PAI-5, Vp-PAI-7, and T3SS2, while the non-pandemic isolates are heterogeneous (Chao et al., 2009). The pandemic 03:K6 strains were detected with toxRS sequence which was useful to differentiate between pandemic and non-pandemic $V$. parahaemolyticus strains (Matsumoto et al., 2000). The differences studied among and between 03:K6 strains led to the definition of non-pandemic 03;K6 strains isolated in 1980-1990 in Asian countries including India, Taiwan, Japan, Thailand, and Bangladesh (Ceccarelli et al., 2013).

Literature stated the presence of filamentous phage $f 237$ in a many 03:K6 isolates which suggests a specific association between the phage and widespread of 03:K6 serotype (Nasu et al., 2000). $V$. parahaemolyticus 03:K6 strains also have orf8 located in the phage and encoding a putative adherence protein which may have 
played important role in increasing the virulence of 03:K6 isolates by being more adhesive to host intestinal cells (Ceccarelli et al., 2013). The genetic traits have been suitable markers for pandemic strains identification however there are inconsistencies noted whereby pandemic O3:K6 strains with atypical profiles isolated in Taiwan, Bangladesh, Japan, and Thailand (Jones et al., 2012).

\section{PREVALENCE OF Vibrio parahaemolyticus}

Seafood is a nutrient rich part of a healthy diet and seafood consumption is associated with various health benefits (Iwamoto et al., 2010). Approximately $90 \%$ of global aquaculture production in based in Asia region. However, along with nutritional benefits from seafood consumption come the potential risks of eating contaminated seafood. Seafood is known as a vehicle of transmission of food borne bacteria that cause human illness worldwide. World Health Organization (WHO) defines food borne illness as a disease which is caused by consumption of contaminated food (Velusamy et al., 2010). Pathogens such as Vibrio species, E. coli 0157:H7, Campylobacter, Salmonella, and Listeria monocytogenes have been found to be responsible for major food borne outbreaks worldwide (Apun et al., 1999; Velusamy et al., 2010). In the Asian region, Vibrio species have been recognized as the leading cause of food borne outbreaks in many countries including Japan, India, China, Taiwan (Hara-Kudo et al., 2003), Korea (Lee et al., 2008), and Malaysia (Tunung et al., 2010). Outbreaks in Asia were reported to be mainly caused by consumption of contaminated seafood (Jacxsens et al., 2009).

In the Asian region, $V$. parahaemolyticus was first recognized as a food borne pathogen in the year 1951 in Osaka, where people frequently consume raw or uncooked seafood (Daniels et al., 2000b). The bacterium was isolated from victims of an outbreak of 272 infected cases and 20 deaths associated with consumption of shirasu, Japanese boiled and semi dried sardines dish (Aberoumand, 2010). Ever since then, V. parahaemolyticus has been commonly isolated from seafood, including shrimp, in markets in South East Asian countries (Elhadi et al., 2004; Deepanjali et al., 2005). V. parahaemolyticus has accounted for many food poisoning cases in Japan ( $\mathrm{Su}$ and Liu, 2007; Aberoumand, 2010; Kubota et al., 2011; Hara-Kudo et al., 2012), in Taiwan (Wong et al., 2000b; Anon, 2005; Yu et al., 2013), in China since early 1990s (Jiang, 1991; Wu et al., 1998; Liu et al., 2004; Li et al., 2014), Bangladesh (Bhuiyan etal., 2002), Laos (Matsumoto et al., 2000), Hong Kong, and Indonesia (Matsumoto et al., 2000).

Pathogenic V. parahaemolyticus was also isolated in Thailand, which is the primary producer and exporter of cultured shrimp worldwide (Yano et al., 2014). A recent study reported the presences of antimicrobial resistance V. parahaemolyticus isolates from white leg shrimp and black leg shrimp cultured at inland ponds in Thailand (Yano et al., 2014). Besides Thailand, pathogenic and antimicrobial resistance V. parahaemolyticus was also isolated from shrimps and cockles in Malaysia (Al-Othrubi et al., 2011). Moreover, in recent years, V. parahaemolyticus has been reported as one of the leading cause of food borne diseases in China (Liu et al., 2004; Chen et al., 2010). Literature has shown that the retail foods in Chinese markets are contaminated by various food borne pathogens such as L. monocytogenes (Chen et al., 2014), Salmonella spp. (Chen et al., 2013), and Campylobacter jejuni (Zheng et al., 2014), and V. parahaemolyticus. In addition, shrimp contaminated with $V$. parahaemolyticus has been associated with outbreaks of food borne illnesses in China (Peng et al., 2010). A recent study reported the isolation of pathogenic trh V. parahaemolyticus from shrimps with the bacteria densities less than $100 \mathrm{MPN} / \mathrm{g}$ in samples (Xu et al., 2014).

In India, V. parahaemolyticus has been isolated both from clinical and environmental samples. In a recent clinical study, 178 V. parahaemolyticus strains were isolated from 13,607 diarrheal patients admitted in Infectious Diseases Hospital, Kolkata since 2001 to 2012 (Pazhani et al., 2014). V. parahaemolyticus diarrheal cases were also detected from the urban slums of Kolkata, India (Kanungo et al., 2012). Reyhanath and Kutty (2014) have reported the detection and isolation of multidrug resistant strains of V.parahaemolyticus from a fishing land at South India. In another study, pathogenic and antibiotic resistant $V$. parahaemolyticus strains along with other Vibrio species strains were isolated from seafood in Cochin. Majority of the strains in this study were resistant to ampicillin and multiple drug resistance was prevalent among the isolates (Sudha et al., 2014). In Taiwan, a study reported the isolation of V. parahaemolyticus from oysters and clam at culturing environments. The isolates exhibited hemolytic or urease activities and presence of $t d h$ gene, $t r h$ gene and T3SS (Yu et al., 2013). The occurrence of pathogenic $V$. parahaemolyticus in seafood and its antimicrobial resistance profile is of public health concern which demands immediate attention.

In Europe, V.parahaemolyticus has been isolated from the Baltic Sea, the North Sea, the Mediterranean Sea (Miwatani and Takeda, 1976), and the Black Sea (Aldova et al., 1971). In 1978, studies were conducted in coastal waters of Guadeloupe and V. parahaemolyticus was isolated from 53 of 100 water samples investigated (Papa, 1980). As years passed, numerous cases of V. parahaemolyticus gastroenteritis were detected and isolated in Spain, Greece, Britain, Turkey, Denmark, Yugoslavia, and the Scandinavian areas (Qadri et al., 2005). A serious outbreak affecting 44 patients associated with consumption of shrimps imported from Asia occurred in France in 1997 (Robert-Pillot et al., 2004). In 1999, there was an outbreak in Galicia, Spain of 64 cases due to consumption of raw oysters (Lozano-Leon et al., 2003). In year 2004, another outbreak was reported in Spain involving 80 cases of V. parahaemolyticus infection among wedding guests in a restaurant. The investigation revealed that the outbreak was caused by consumption of boiled crab prepared under unsanitary conditions (Martinez-Urtaza et al., 2005).

In 1971, V.parahaemolyticus was first identified as an etiological food borne pathogen in Maryland, U.S. after three outbreaks of 425 gastroenteritis cases associated with consumption of improperly cooked crabs (Molenda et al., 1972). Ever since then, intermittent V.parahaemolyticus outbreaks have been reported throughout the U.S. coastal regions due to the consumption of raw shellfish or uncooked seafood. The Centers for Disease Control and Prevention [CDC] (1998) have reported about 40 outbreaks of $V$. parahaemolyticus infection from the year 1973 to 1998 (Daniels et al., 2000a). Four out of the 40 outbreaks involved over 700 cases of diseases linked with consumption of raw oyster in the Gulf 
Coast, Pacific Northwest, and Atlantic Northeast regions between the years 1997 to 1998 . During the summer of 1997, there were 209 (including one death) of $V$. parahaemolyticus infection cases reported involving raw oyster consumption in the Pacific Northwest (Oregon, Washington, California, and British Columbia of Canada; Centers for Disease Control and Prevention [CDC], 1998). Two outbreaks of 43 cases in Washington and 416 cases in Texas in the 1998 were also associated with consumption of raw oyster (DePaola et al., 2000). Another small outbreak of eight cases of V. parahaemolyticus illnesses was reported in Connecticut, New Jersey, and New York between July and September in 1998 as a result of eating oysters and clams harvested at Long Island Sound of New York (Centers for Disease Control and Prevention [CDC], 1999). In summer 2004, 14 passengers on board a cruise ship in Alaska manifested gastroenteritis symptoms after ingestion raw oysters produced in Alaska (McLaughlin et al., 2005). The O6:K18 isolates from the Alaskan outbreak were in distinguishable by PFGE from those isolated in the sporadic cases from Pacific Coast states over the previous decade. From July to October of 2004, 96 environmental samples were collected from 17 Alaskan oyster farms, and 31 samples (32\%) tested positive for V. parahaemolyticus. The most frequently occurring serotypes were O1:K9, O4:K63, and O6:K18 (Newton et al., 2012). In summer 2006, an outbreak occurred involving 177 cases of $V$. parahaemolyticus associated with consumption of contaminated oysters harvested in Washington and British Columbia (Centers for Disease Control and Prevention [CDC], 2006).

Pandemic V. parahaemolyticus strains were also isolated in The United States. The O4:K12 serotype showed the highest prevalence among tested clinical V. parahaemolyticus isolates from the U.S. Pacific Coast between 1979 and 1995 (DePaola et al., 2003). In 1998, another outbreak occurred involving 416 individuals from 13 states across U.S. after consumption of raw oysters. From the available patients stool samples, $V$. parahaemolyticus O3:K6 was isolated, which closely resembled the pandemic Asian O3:K6 isolates by PFGE (Daniels et al., 2000a). Clinical isolates in the U.S., especially from the Pacific Northwest are found to be encoded with trh gene (Paranjpye et al., 2012). In addition, there was an increase in clinical isolates possessing either $t d h$ gene, trh gene or both, and these severe cases required hospitalization $(\mathrm{FAO} / \mathrm{WHO}$, 2011). These incidents of $V$. parahaemolyticus contamination in oysters reflect a serious safety concern in the U.S.

Current studies have reported that environmental factors which include interaction with other hosts play a huge effect in the evolution of certain pathogens (Wilson and Salyers, 2003). Therefore, the pandemic strains that exhibit certain biological characteristics such as increased toxin production or having the capability to live within the natural environment could give better insights into the mechanisms underlying the emergence and spread of these strains (Wong et al., 2000a). The prevalence and distribution of V. parahaemolyticus is known to be influenced by several environmental factors including the water temperature, salt and oxygen concentrations, interaction with plankton, presence of sediment, organic matter in suspension and marine organisms (Cabrera-Garcia et al., 2004). Despite the advances in hygiene, food treatment and food processing, this food borne pathogen still represents a significant threat to human health worldwide.

\section{IDENTIFICATION OF Vibrio parahaemolyticus ENRICHMENT MEDIA AND SELECTIVITY}

Vibrio parahaemolyticus is recognized as a cause of food borne illness that is associated with seafood consumptions. Hence, various selective enrichment media have been utilized for the isolation and detection of V. parahaemolyticus (Paydar et al., 2013). Due to its natural presence in the marine environments with high tolerance and preference to alkaline $\mathrm{pH}$ condition, the selective media used for this pathogen is often prepared for $\mathrm{pH} 8.6-\mathrm{pH}$ 9.4, alkaline with the additional $1-7 \% \mathrm{NaCl}$. In certain condition, the media is supplemented with extra surfactants such as sodium dodecyl sulphate (SDS) and alkylbenzene sulphonate, bile salts, dyes such as metachrome yellow II RD, and antibiotics such as colistin or polymyxin B (Donovan and Van Netten, 1995).

The U.S. Food and Drug Administration (FDA) have recommended alkaline peptone water (APW) as the enrichment broth for all Vibrio species including V. parahaemolyticus (Farmer et al., 2003; DePaola and Kaysner, 2004). APW has a pH level between $\mathrm{pH} 8.5-\mathrm{pH} 9$ and high concentration of $\mathrm{NaCl}$ which inhibits the growth of other bacteria (DePaola and Kaysner, 2004). Preparation of this APW, $10.0 \mathrm{~g}$ Peptone and $10.0 \mathrm{~g} \mathrm{NaCl}$ in $1000 \mathrm{ml}$ distilled water. The $\mathrm{pH}$ is adjusted to $8.5 \pm 0.1$ and autoclaved at $121^{\circ} \mathrm{C}$ for 10 min. Besides APW, salt polymyxin broth (SPB), alternative protein source (APS) broth, salt colistin broth, glucose salt teepol broth and bile salt sodium taurocholate (ST broth) can be used as an enrichment broth for Vibrio species (Bisha et al., 2012). In a study, the results stated higher percentage of isolation and identification of pathogenic V. parahaemolyticus strains from seafood samples by using ST broth compared to APW (Raghunath et al., 2009). Hara-Kudo et al. (2001) have developed a procedure that consists of a non-selective enrichment step in salt trypticase soy broth followed by a selective enrichment step in SPB. This two step enrichments procedure was found to be more effective to isolate $V$. parahaemolyticus compared to the one step enrichment in SPB alone. SPB contains Polymyxin B sulfate that inhibits the growth of gram-positive organisms.

Various selective media have been developed for isolation and identification of $V$. parahaemolyticus. The most common selective media is thiosulphate citrate bile salts sucrose (TCBS), a highly selective differential medium that is widely used not only for Vibrio cholerae but all other pathogenic Vibrios except Vibrio hollisae (Kobayashi et al., 1963). TCBS is a selective system consisting of ox bile $(0.8 \%), \mathrm{NaCl}(1 \%)$ and alkaline $\mathrm{pH} 8.6$ which suppresses the of growth other interfering gram positive organisms. The main advantage of TCBS agar is its sucrose/bromothymol blue diagnostic system which differentiates sucrose-positive Vibrios such as V. cholerae from other Vibrio species colonies. $V$. cholerae would resemble notable colony morphology of 2-3 mm, yellow colonies on TCBS agar (Mrityunjoy et al., 2013). V.parahaemolyticus colonies would be typical 2-3 $\mathrm{mm}$ diameter, round, opaque, green, or bluish colonies (Bisha et al., 2012).

As year passed, researchers have noted from surveys of seafood studies that V. parahaemolyticus colonies on TCBS agar are difficult to distinguish physically from other bacterial colonies. Since TCBS is a general media used for all Vibrio isolation, a huge amount of yellow colonies produced by sucrose-fermenting bacteria or 
green colonies will grow on this media and make it difficult to effectively isolate and enumerate V. parahaemolyticus from samples (Pinto etal., 2011; Bisha et al., 2012). To offset this issue, Hara-Kudo et al. (2001) developed a new enrichment procedure and selective agar medium for detecting $V$. parahaemolyticus in seafood. The samples were cultured in selective SPB and plated on the chromogenic CHROMagar Vibrio (CV) agar (CHROMagar Microbiology, Paris, France). CHROMagar contains colorimetric substrates for $\beta$-galactosidase and was developed specifically to differentiate ortho-nitrophenyl- $\beta$-galactoside-positive $V$. parahaemolyticus from other closely related Vibrio species (Bisha et al., 2012). On this chromogenic medium, the mauve color V. parahaemolyticus colonies are easily distinguished and differentiated from other Vibrio species. Many researchers have compared the use of CV and TCBS, and reported higher percentage of detection rate for $\mathrm{CV}$ compared to TCBS. The results indicate $\mathrm{CV}$ is more specific and accurate than TCBS in detecting $V$. parahaemolyticus (Su and Liu, 2007).

The Wagatsuma agar was developed and used in the Kanagawa Phenomenon. This agar is made up of human or rabbit blood with $\mathrm{NaCl}$, mannitol, crystal violet and $\mathrm{K}_{2} \mathrm{HPO}_{4}$. The main advantage of this agar is to assist in differentiation of $t d h$ and non- $t d h$ producing strains. $V$. parahaemolyticus strains which produce $t d h$ gene will hemolysis a halo on this Wagatsuma agar (Nishibuchi and Kaper, 1995; Qadri et al., 2005; Alipour et al., 2014). The main disadvantage of this media is that the agar cannot differentiate $t r h$ $V$. parahaemolyticus strains from the non-pathogenic strains. The trh strains will not exhibit hemolysis characteristic on Wagatsuma agar.

\section{CULTURAL DETECTION AND ENUMERATION}

The enumeration of $V$. parahaemolyticus from seafood is important in the context of current FDA guidelines which indicate that shellfish should contain less than 10,000 V. parahaemolyticus cells per g (Deepanjali etal., 2005). In line with that, the most probable number (MPN) method was described by U.S. FDA Bacterial Analytical Manual in detecting Vibrio species in food samples. MPN is a conventional method that estimates the population density of viable microorganisms in a sample. This method is based upon the application of the theory of probability to the numbers of observed positive growth responses to a standard dilution series of sample inoculum placed into a set of replicate liquid broths (Sutton, 2010). The important perception of the MPN technique is to dilute the sample to an extent that inoculums in the tubes will contain viable organisms. Through replicates and dilution series, the results would be reasonably accurate in estimating the most probable number of cells in the sample. In addition, the nutrient broth used would support growth of organism and turn cloudy. This basic identification step of growth versus no growth provides useful information for low number of organisms (Sutton, 2010). This traditional enumeration method is usually employed during the identification process to identify and enumerate $V$. cholerae and V. parahaemolyticus (Nishibuchi, 2006). The FDA has described either a 10-fold, fivefold, or threefold serial dilution MPN tube with selective enrichment broth and agar medium to enumerate $V$. cholerae and V. parahaemolyticus in seafood samples (Kaysner and
DePaola, 2004). The method involves an overnight enrichment in APW, the standard enrichment for Vibrio species detection and then incubated for $18-24 \mathrm{~h}$ at $35-37^{\circ} \mathrm{C}$. The tubes showing turbidity are cultured on TCBS, a highly selective differential medium that is widely used not only for $V$. cholerae but all other pathogenic Vibrios except $V$. hollisae (Kobayashi et al., 1963). In addition, many studies have successfully employed MPN method coupled with selective media CV agar to achieve higher and better isolation of $V$. parahaemolyticus colonies in comparison to the selective TCBS agar (Hara-Kudo et al., 2003; Miyasaka et al., 2006; Blanco-Abad et al., 2009).

Although the conventional detection method is useful in detecting and isolating Vibrio species, the method has several major drawbacks. The amount of workload, materials, and the time needed to complete the whole identification process usually takes 7-10 days (Tunung et al., 2011). Hence, to overcome the disadvantages, the MPN method is combined with a species specific polymerase chain reaction (PCR) method. This MPNPCR method enables the completion of enumeration of bacterial from the environment or seafood samples within 2 days (Miwa et al., 2003; Martin etal., 2004). It is established that the PCR has proven to be very useful because of its ability to amplify a specific DNA segment by a factor of $10^{6}$ or more within hours, therefore potentially permitting detection of very limited amounts of cells (Alam et al., 2003). Other researchers have reported the success of MPN-PCR method in detecting specific gene in the organism instead of isolation of the target organism to enumerate the bacteria in environmental and food samples (Alam etal., 2002), in soil samples (Vesa etal., 1997) and V. parahaemolyticus (Hara-Kudo et al., 2003; Miwa et al., 2003, 2006). The MPN-PCR method can be readily applied using any targeted primer, without extensive developmental work (Luan et al., 2008).

Another alternative approach to the detection and characterization of $V$. parahaemolyticus is via colony hybridization. Colony hybridization technique is a combination of plate count and confirmation based on the identity of the colony through DNA hybridization. Usually most hybridization uses speciesspecific probes based on variable regions of the 16S rRNA (Thompson et al., 2004). Many studies have described the enumeration using radioactive DNA probes or non-radioactive DNA probes in colony hybridization (Deepanjali et al., 2005). The method was used to confirm the presence and number of total and pathogenic V. parahaemolyticus (DePaola et al., 2000, 2003). Suffredini et al. (2014a) proposed that colony hybridization could be a suitable method for the enumeration of total and potentially pathogenic $V$. parahaemolyticus in seafood.

\section{MOLECULAR DETECTION OF Vibrio parahaemolyticus}

The conventional phenotyping and biochemical identification techniques of $V$. parahaemolyticus are complicated when the strains are isolated from seafood and aquatic environments (Nishibuchi, 2006). As a result, PCR based assay has become a popular molecular technique for identification and detection of $V$. parahaemolyticus (Drake et al., 2007). The genetic composition of Vibrio species is extremely variable thus the genes present inside a targeted strain of Vibrio can be used to distinguish the genus 
from other bacteria and are obvious candidates for the development of DNA based methods for identification of Vibrio species (Foley et al., 2009). In fact, a number of researchers have studied pandemic isolates to carry bacteriophage sequences that non pandemic strains do not, and they have exploited these differences to develop pandemic strain-specific detection methods (Bisha et al., 2012). To increase the output and lessen the reagent costs, PCR primers can be multiplexed in a single reaction or tailored for the real-time PCR analysis to provide more rapid results (Grant et al., 2006).

Polymerase chain reaction is a method with high sensitivity and specificity for detection and identification of pathogenic bacteria from clinical, environmental or seafood samples (Nelapati et al., 2012). PCR method was developed to identify $V$. parahaemolyticus strains at the species level by targeting toxR gene (Vimala et al., 2010; Paydar et al., 2013; Suffredini et al., 2014b). The toxR gene stimulates the expression of $t d h$ gene and it is present in either pathogenic or non-pathogenic $V$. parahaemolyticus isolates (Sujeewa et al., 2009). Alternatively, the thermolabile hemolysin (tlh) in V. parahaemolyticus is another gene that was used to develop a multiplex PCR procedure for simultaneous detection of total and virulent V. parahaemolyticus (Yi et al., 2014) Although, the th gene is not considered a virulence factor of $V$. parahaemolyticus, the gene is reported to be a reliable marker for the bacteria (Su and Liu, 2007). Bej et al. (1999) reported a multiplex PCR protocol for amplification of $t h h, t d h$, and $t r h$, which could be employed for detecting total and virulent $V$. parahaemolyticus in shellfish. The outcome of results detected th gene in all 111 strains of $V$. parahaemolyticus isolated from clinical, seafood, environmental, and oyster plants with sensitivity for detecting all three genes of at least 1-10 cells per gram of APW enriched sample homogenate.

Multiplex PCR assays have been very popular and are utilized to differentiate V. parahaemolyticus, V. cholerae, and Vibrio alginolyticus from each other (Di Pinto et al., 2005; Wei et al., 2014). Kaufman etal. (2004) used PCR on samples of oyster mantle fluid, rather than homogenized meat, and reported that V. parahaemolyticus levels in the mantle fluid were highly correlated to levels in oyster tissues with $r=0.85$. Many PCR assays have been employed to affect detection of the $t d h$ or $t r h$ genes (Dileep et al., 2003). In addition, real-time PCR has been used to detect total and pathogenic $V$. parahaemolyticus in seafood samples (Nordstrom et al., 2007). Real-time PCR has the ability to process huge number of samples with speed and consistency in a single tube amplification targeting the gene (McKillip and Drake, 2000). Ward and Bej (2006) developed a multiplexed real-time PCR TaqMan assay that targeted four different genes and was capable of detecting total and pathogenic V. parahaemolyticus, including the pandemic O3:K6 serotype in shellfish. The gene targets included the $t d h$ and trh genes (detection of pathogenic V. parahaemolyticus), ORF8 (detection of pandemic V. parahaemolyticus O3:K6) and th gene for the detection of total $V$. parahaemolyticus. Real time PCR was successfully used to detect $t$ dh gene (Blackstone et al., 2003) and $t$ th gene (Kaufman et al., 2004) in V. parahaemolyticus using specific primer sets and fluorogenic probes.

Current advancement in PCR technology has led to the development of loop mediated isothermal amplification (LAMP) based assays as an alternative to PCR (Notomi et al., 2000). The main advantage of LAMP-based assays as compared to PCR is that during LAMP, nucleic acid amplification occurs at a single temperature, eliminating the need for thermal cyclers. Nemoto et al. (2009) utilized LAMP to detect $t d h$-positive isolates of $V$. parahaemolyticus targeting six regions of the $t d h$ gene and compared the results to PCR for detection of $t d h$ and reverse passive latex agglutination for $t d h$ detection. Another LAMP assay was developed for detection of th gene and tested both with pure $V$. parahaemolyticus cultures and artificially inoculated shrimp. The assay revealed all 143 pure $V$. parahaemolyticus culture were positive, while no LAMP product was detected from any of 33 non- $V$. parahaemolyticus or 56 non-Vibrio isolates (Yamazaki et al., 2008). LAMP consistently identified 2.0 CFU per reaction, while PCR required $\sim 10$-fold more bacteria for detection. Later, Yamazaki et al. (2010) followed up on their previous work by developing a LAMP assay to detect the $t d h$ and $t r h$ genes in $V$. parahaemolyticus and related Vibrio species. LAMP assays was also successfully used targeting rpoD and toxR genes of $V$. parahaemolyticus which resulted in positive detection of $78 \mathrm{~V}$. parahaemolyticus strains (Nemoto et al., 2011). The detection LAMP assay sensitivity targeting $r p o D$ and toxR was determined to be 3.7 and $450 \mathrm{CFU}$ per test in pure culture. The rpoD-LAMP assay was combined with MPN method detection for detection of $V$. parahaemolyticus in spiked short-necked clams comparative to MPN method with a culture method using agar medium. The results showed higher sensitivity using the rpoD-LAMP method (Nemoto et al., 2011).

Besides PCR and LAMP assays, there are many other molecular methods (Table 1) employed to detect $V$. parahaemolyticus from samples. The random amplified polymorphic DNA-PCR (RAPD-PCR) is another approach commonly used for typing and differentiation of bacteria. This method increases study of genetic relationships between strains and microorganisms, plants or animals species (Oakey et al., 1998). Wong and Lin (2001) used and developed three different PCR methods namely RSPCR, REP-PCR, and ERIC-PCR to detect V. parahaemolyticus to avoid the use of random primers. It was reported REP-PCR is better than ERIC-PCR due to greater reproducibility. Another approach of detecting Vibrio parahaemloyticus is through fluorescence in situ hybridisation, a method that employs fluorescently labeled short nucleotides to specifically hybridize targeted rRNA in whole permeabilised cells. Sawabe et al. (2009) employed a multi-probe approach (using designed probes VP437, VP612, and VP1253); however, the assay was only species specific, which would only allow for employment of this method to detect total $V$. parahaemolyticus.

The emergence of a pandemic clone of $V$. parahaemolyticus and its widespread distribution has led to the development of specific method to detect such strains. A group-specific PCR (GSPCR) based on the sequence variation in the toxRS operon was developed to differentiate between pandemic and non-pandemic strains (Matsumoto et al., 2000). But other researchers claimed that the occurrence of GS-PCR positive V. parahaemolyticus strains do not belong to the pandemic clone group (Vongxay et al., 2008). GS-PCR or orf8-PCR was developed as a diagnostic tool to identify the pandemic clone group (Nasu et al., 2000). 
Table 1 | Listof molecular methods for Vibrio parahaemolyticus detection.

\begin{tabular}{|c|c|c|c|}
\hline Methods & Sensitivity/specificity & Advantages/disadvantages & arget and reference \\
\hline $\begin{array}{l}\text { Polymerase chain } \\
\text { reaction (PCR) }\end{array}$ & $\begin{array}{l}\text { Sensitivity: } \\
\text { Highly sensitive but depends on the } \\
\text { PCR program, target separation and } \\
\text { enrichment. } \\
\text { Specificity: } \\
\text { It is highly specific. PCR can be utilized } \\
\text { for the detection of total, } \\
\text { environmental, pathogenic strains, or } \\
\text { even specific serovars. }\end{array}$ & $\begin{array}{l}\text { Advantages: } \\
\text { Provides quick, precise, and sensitive results. } \\
\text { PCR allows differentiation of pathogenic vs. } \\
\text { environmental strains and can be optimized to } \\
\text { detect definite serovars. Can be performed as } \\
\text { multiplex PCR. } \\
\text { Disadvantages: } \\
\text { Its sensitivity is hindered by non optimized } \\
\text { protocols or enrichments. }\end{array}$ & $\begin{array}{l}\text { tdh, trh, toxR (Bhuiyan et al., } \\
\text { 2002), tlh, tdh, trh (Nordstrom } \\
\text { etal., 2007), thh, tdh, trh, } \\
\text { ORF8 Ward and Bej, 2006), } \\
\text { toxR, tdh, trh (Paydar et al., } \\
\text { 2013), tdh, trh (Suffredini et al., } \\
\text { 2014b) }\end{array}$ \\
\hline $\begin{array}{l}\text { Loop-mediated } \\
\text { isothermal amplification } \\
\text { (LAMP) }\end{array}$ & $\begin{array}{l}\text { Sensitivity: } \\
\text { LAMP is very sensitivity compared to } \\
\text { cultural method and even PCR. } \\
\text { Specificity: } \\
\text { LAMP is less susceptible to } \\
\text { interference with } 100 \% \text { specificity. The } \\
\text { use of many primers in LAMP provides } \\
\text { a greater specificity. Could be used to } \\
\text { detect environmental, pathogenic or } \\
\text { both strains of Vibrio parahaemolyticus. }\end{array}$ & $\begin{array}{l}\text { Advantages: } \\
\text { LAMP is simplicity, cost-effective and versatile } \\
\text { method which provides rapid results to detect } \\
\text { the infected bacteria. Can be performed at one } \\
\text { temperature without the need of cycling. } \\
\text { Disadvantages: } \\
\text { Similar to PCR, it affected by methods of } \\
\text { targeted separation and enrichments. }\end{array}$ & $\begin{array}{l}\text { thh (Yamazaki et al., 2008), tdh } \\
\text { (Nemoto et al., 2009), tdh, } \\
\text { trh1, and trh2 (Yamazaki et al., } \\
\text { 2010), rpoD and toxR (Nemoto } \\
\text { etal., 2011), Vibrio } \\
\text { parahaemolyticus (Sun et al., } \\
\text { 2011), Vibrio parahaemoluticus } \\
\text { tlh gene (Zeng et al., 2014) }\end{array}$ \\
\hline DNA hybridisation & $\begin{array}{l}\text { Sensitivity: } \\
\text { Compared to cultural method, it is } \\
\text { higher sensitive. } \\
\text { Specificity: } \\
\text { Can be used to detect environmental, } \\
\text { pathogenic or both strains of Vibrio } \\
\text { parahaemolyticus. }\end{array}$ & $\begin{array}{l}\text { Advantages: } \\
\text { FDA-BAM suggested method used for Vibrio } \\
\text { parahaemolyticus identification. Improved } \\
\text { rapidity and specificity compared to culture } \\
\text { method. } \\
\text { Disadvantages: } \\
\text { Depends on culture methods which affect the } \\
\text { rapidity of detection. }\end{array}$ & $\begin{array}{l}\text { tdh (Lee et al., 1992; } \\
\text { Nordstrom and DePaola, } \\
\text { 2003), thh (Ellison et al., 2001; } \\
\text { Gooch et al., 2001) }\end{array}$ \\
\hline $\begin{array}{l}\text { FISH- fluorescence in } \\
\text { situ hybridisation and } \\
\text { recognition of individual } \\
\text { gene fluorescence in situ } \\
\text { hybridisation } \\
\text { (RING_FISH) }\end{array}$ & $\begin{array}{l}\text { Sensitivity: } \\
\text { It is a sensitive method applied to } \\
\text { detect Vibrio parahaemolyticus. } \\
\text { Specificity: } \\
\text { However, at this point, the } \\
\text { differentiation can be done at species } \\
\text { level only. }\end{array}$ & $\begin{array}{l}\text { Advantages: } \\
\text { Helps to enumerate the number of bacteria in a } \\
\text { sample even if low in number. Rapid and specific } \\
\text { results. } \\
\text { Disadvantages: } \\
\text { This method is unable to differentiate pathogenic } \\
\text { Vibrio parahaemolyticus from environmental } \\
\text { isolates. Depends on culture methods which } \\
\text { affect the rapidity of detection. }\end{array}$ & $\begin{array}{l}\text { rRNA (Sawabe etal., 2009), th } \\
\text { (Griffitt etal., 2011) }\end{array}$ \\
\hline Real-Time PCR & $\begin{array}{l}\text { Sensitivity: } \\
\text { More sensitive than the conventional } \\
\text { PCR. It can reduce enrichment step and } \\
\text { detect low number of pathogens in a } \\
\text { sample. } \\
\text { Specificity: } \\
\text { The use of fluorescent probes gives the } \\
\text { assay a high level of specificity in } \\
\text { detecting targeted bacteria from } \\
\text { samples. }\end{array}$ & $\begin{array}{l}\text { Advantages: } \\
\text { Very efficient, useful, rapid and easy to use in } \\
\text { detection of pathogenic Vibrios in seafood. The } \\
\text { method does not require post-PCR step. } \\
\text { Process by measuring the accumulation of PCR } \\
\text { amplicons during each Real Time PCR cycle. The } \\
\text { assay could be multiplexed for faster detection. } \\
\text { Disadvantages: } \\
\text { May amplify dead cells that are not detectable } \\
\text { thru cultural methods and amplification could be } \\
\text { false positive result. }\end{array}$ & $\begin{array}{l}\text { gyrB, pR72H, th, toxR, tdh, } \\
\text { and trh genes Nenkateswaran } \\
\text { etal., 1998; Bej et al., 1999; } \\
\text { Kim etal., 1999; Davis et al., } \\
\text { 2004; Ward and Bej, 2006; } \\
\text { Nordstrom et al., 2007; } \\
\text { Robert-Pillot et al., 2010; He } \\
\text { et al., 2014) }\end{array}$ \\
\hline
\end{tabular}


PFGE of NotI digested genomic DNA is a good molecular tool to differentiate between pandemic and non pandemic strains. This method is more appropriate then ribotyping using EcoRI, RAPDPCR, GS-PCR, and orf8-PCR because it produces many diverse patterns and groups the pandemic strains in closely related clusters (Yeung et al., 2002). Many studies have utilized this method and validated the reproducibility and discriminatory nature of PFGE (Fakruddin et al., 2013). PFGE is also able to produce results of the genetic diversity among strains which is important information that is not provided by GS-PCR or orf8-PCR. A few studies have stated that repetitive sequenced based PCR is found to be slightly more discriminatory compared to PFGE as it generates greater numbers of different patterns and was less likely to yield untypeable results caused by DNA degradation (Wong and Lin, 2001).

\section{CONCLUSION}

The concerns about health consequences from Vibrio species, especially when seafood remains as a vehicle of transmission of Vibrio, are likely to continue in future. Over the last decade, at least one new Vibrio species has been reoccurring per year that could be transmitted through the environment as a new public health threat. This is due to a number of factors including: (i) progress in molecular biology, which allows identification of new strains and locates its source; (ii) the evolution of pathogens; and (iii) application of microbial risk assessment to quantify risks from environmentally transmitted pathogens (Igbinosa and Okoh, 2008). Therefore, to establish effective control measures to reduce the risk infection by this bacterium and to ensure the safety of foods; surveillance and epidemiology as well as the employment of molecular methods for the detection of $V$. parahaemolyticus in food and environment is very important. Phenotypic and molecular detection will continue to be useful in isolating and identifying of $V$. parahaemolyticus as this bacteria continues to emerge as a food borne pathogen.

\section{ACKNOWLEDGMENTS}

This work was supported by a University of Malaya for High Impact Research Grant (UM-MOHE HIR Nature Microbiome Grant No. H-50001-A000027) awarded to Kok-Gan Chan and External Industry Grants from Biotek Abadi Sdn Bhd (vote no. GBA-808138 and GBA-808813) awarded to Learn-Han Lee.

\section{REFERENCES}

Aberoumand, A. U. (2010). Occurrence anzd pathogenic vibrios in the marine environment of potentially pathogenic the straits of Messina, Italy. World J. Fish Mar. Sci. 3, 376-382. doi: 10.1016/j.marpolbul.2005.02.045

Alam, M. J., Miyoshi, S., and Shinoda, S. (2003). Studies on pathogenic Vibrio parahaemolyticus during a warm weather in the Seto Inland Sea, Japan. J. Environ. Microbiol. 5, 706-710. doi: 10.1046/j.1462-2920.2003.00458.x

Alam, M. J., Tomochika, K. I., Miyoshi, S. I., and Shinoda, S. (2002). Environmental investigation of potentially pathogenic Vibrio parahaemolyticus in the Seto-Inland Sea, Japan. FEMS Microbiol. Lett. 208, 83-87. doi: 10.1111/j.15746968.2002.tb11064.x

Aldova, E., Zakhariev, Z. A., Dinev, T. S., and Zlatanov, Z. T. (1971). Vibrio parahaemolyticus in the Black Sea. Zentralbl. Bakteriol. Orig. A A218, 176-188.

Alipour, M., Issazadeh, K., and Soleimani, J. (2014). Isolation and identification of Vibrio parahaemolyticus from seawater and sediment samples in the southern coast of the Caspian Sea. Comp. Clin. Path. 23, 129-133. doi: 10.1007/s00580012-1583-6
Al-Othrubi, S. M., Hanafiah, A., Radu, S., Neoh, H., and Jamal, R. (2011). Rapid detection and E-test antimicrobial susceptibility testing of Vibrio parahaemolyticus isolated from seafood and environmental sources in Malaysia. Saudi Med. J. 32, 400-406.

Anon. (2005). Food Poisoning in Taiwan 1981-2003. Department of Health, Taiwan. Available at: http://food.doh.gov.tw/chinese/academic/academic2_1.htms

Apun, K., Asiah, M. Y., and Jugang, K. (1999). Distribution of bacteria in tropical freshwater fish and ponds. Int. J. Environ. Res. Public Health 9, 285-292. doi: 10.1080/09603129973083

Bej, A. K., Patterson, D. P., Brasher, C. W., Vickery, M. C., Jones, D. D., and Kaysner, C. A. (1999). Detection of total and hemolysin-producing Vibrio parahaemolyticus in shell fish using multiplex PCR amplification of tl, tdh and trh. J. Microbiol. Methods 36, 215-225. doi: 10.1016/S0167-7012(99)00037-8

Bhuiyan, N. A., Ansaruzzaman, M., Kamruzzaman, M., Alam, K., Chowdhury, N. R., Nishibuchi, M., et al. (2002). Prevalence of the pandemic genotype of Vibrio parahaemolyticus in Dhaka, Bangladesh, and significance of its distribution across different serotypes. J. Clin. Microbiol. 40, 284-286. doi: 10.1128/JCM.40.1.284286.2002

Bisha, B., Simonson, J., Janes, M., Bauman, K., and Goodridge, L. D. (2012). A review of the current status of cultural and rapid detection of Vibrio parahaemolyticus. Int. J. Food Sci. Tech. 47, 855-899. doi: 10.1111/j.1365-2621.2012.02950.x

Blackstone, G. M., Nordstrom, J. L., Vickery, M. C. L., Bowen, M. D., Meyer, R. F., and DePaola, A. (2003). Detection of pathogenic Vibrio parahaemolyticus in oyster enrichment by real-time PCR. J. Microbiol. Methods 53, 149-155. doi: 10.1016/S0167-7012(03)00020-4

Blanco-Abad, V., Ansede-Bermejo, J., Rodriguez-Castro, A., and Martinez-Urtaza, J. (2009). Evaluation of different procedures for the optimized detection of Vibrio parahaemolyticus in mussels and environmental samples. Int. J. Food Microbiol. 129, 229-236. doi: 10.1016/j.ijfoodmicro.2008.11.028

Boyd, F. E., Cohen, L. V. A., Naughton, M. L., Ussery, W. D., Binnewies, T. T., Stine, C. O., et al. (2008). Molecular analysis of the emergence of pandemic Vibrio parahaemolyticus. BMC Microbiol. 8:110. doi: 10.1186/1471-2180-8-110

Broberg, C. A., Calder, T. J., and Orth, K. (2011). Vibrio parahaemolyticus cell biology and pathogenicity determinants. Microbes Infect. 13, 992-1001. doi: 10.1016/j.micinf.2011.06.013

Broberg, C. A., Zhang, L., Gonzalez, H., Laskowski-Arce, M. A., and Orth, K. (2010). A Vibrio effector protein is an inositol phosphatase and disrupts host cell membrane integrity. Science 329, 1660-1662. doi: 10.1126/science.1192850

Burdette, D. L., Yarbrough, M, L., Orvedahl, A., Gilpin, C, J., and Orth, K. (2008). Vibrio parahaemolyticus orchestrates a multifaceted host cell infection by induction of autophagy, cell rounding, and then cell lysis. Proc. Natl. Acad. Sci. U.S.A. 105, 12497-12502. doi: 10.1073/pnas.0802773105

Cabrera-Garcia, M. E., Vazquez-Salinas, C., and Quinones-Ramirez, E. I. (2004). Serologic and molecular characterization of Vibrio parahaemolyticus strains isolated from seawater and fish products of the Gulf of Mexico. Appl. Environ. Microbiol. 70, 6401-6406. doi: 10.1128/AEM.70.11.6401-6406.2004

Canizalez-Roman, A., Flores-Villasenor, H., Zazueta-Beltran, J., Muro-Amador, S., and Leon-Sicairos, N. (2011). Comparative evaluation of a chromogenic agar medium-PCR protocol with a conventional method for isolation of Vibrio parahaemolyticus strains from environmental and clinical samples. Can. J. Microbiol. 57, 136-142. doi: 10.1139/W10-108

Ceccarelli, D., Hasan, N, A., Hug, A., Colwell, R. R. (2013). Distribution, and dynamics of epidemic, and pandemic Vibrio. (parahaemolyticus) virulence factors. Front. Cell. Infect. Microbiol. 3:97. doi: 10.3389/fcimb.2013.00097

Centers for Disease Control, and Prevention [CDC]. (1998). Outbreak of Vibrio parahaemolyticus infections associated with eating raw oysters-Pacific Northwest, 1997. Morb. Mortal. Wkly. Rep. 47, 457-462.

Centers for Disease Control and Prevention [CDC]. (1999). Outbreak of Vibrio parahaemolyticus infection associated with eating raw oysters, and clams harvested from Long Island Sound-Connecticut. New Jersey and New York, 1998. Morb. Mortal. Wkly. Rep. 48, 48-51.

Centers for Disease Control and Prevention [CDC]. (2006). Vibrio parahaemolyticus Infections associated with consumption of raw shellfish at three states, 2006. Morb. Mortal. Wkly. Rep. 55, 1-2.

Chao, G., Jiao, X., Zhou, X., Yang, Z., Huang, J., Pan, Z., et al. (2009). Serodiversity, pandemic O3:K6 clone, molecular typing and antibiotic susceptibility of food borne and clinical Vibrio parahaemolyticus isolates in Jiangsu, China. Foodborne Pathog. Dis. 6, 1021-1028. doi: 10.1089/fpd.2009.0295 
Chen, L., Zhang, J., Yang, X., Wu, Q., and Xu, M. (2013). Prevalence and characterization of Salmonella spp. from foods in South China. Acta Microbiol. Sin. 53, 1326-1333.

Chen, M., Wu, Q., Zhang, J., Yan, Z., and Wang, J. (2014). Prevalence and characterization of Listeria monocytogenes isolated from retail-level ready-to-eat foods in South China. Food Control 38, 1-7. doi: 10.1016/j.foodcont.2013.09.061

Chen, Y., Liu, X. M., Yan, J. W., Li, X. G., Mei, L. L., Fa, Q. M., et al. (2010). Foodborne pathogens in retail oysters in south China. Biomed. Environ. Sci. 23, 32-36. doi 10.1016/S0895-3988(10)60028-1

Cornelis, G. R. (2006). The type III secretion injectisome. Nat. Rev. Microbiol. 4 811-825. doi: 10.1038/nrmicro1526

Daniels, N. A., MacKinnon, L., Bishop, R., Altekruse, S., Ray, B., Hammond, R. M., et al. (2000a). Vibrio parahaemolyticus infections in the United States, 1973-1998. J. Infect. Dis. 181, 1661-1666. doi: 10.1086/315459

Daniels, N. A., Ray, B., Easton, A., Marano, N., Kahn, E., McShan, A. L., et al. (2000b). Emergence of a new O3:K6 Vibrio parahaemolyticus serotype in raw oysters. JAMA 284, 1541-1545. doi: 10.1001/jama.284.12.1541

Davis, C. R., Heller, L. C., Peak, K. K., Wingfield, L., Goldstein-Hart, C. L., Bodager, D. W., et al. (2004). Real-time PCR detection of the thermostable direct hemolysin and thermolabile hemolysin genes in a Vibrio parahaemolyticus cultured from mussels and mussel homogenate associated with a food borne outbreak. J. Food Prot. 67, 1005-1008.

Deepanjali, A., Kumar, H. S., Karunasagar, I., and Karunasagar, I. (2005). Seasonal variation in abundance of total and pathogenic Vibrio parahaemolyticus bacteria in oysters along the southwest coast of India. Appl. Environ. Microbiol. 71, 35753580. doi: 10.1128/AEM.71.7.3575-3580.2005

DePaola, A., and Kaysner, C. A. (2004). Vibrio. Bacteriological Analytical Manual Online. Washington, DC: U.S. Food and Drug Administration.

DePaola, A., Kaysner, C. A., Bowers, J., and Cook, D. W. (2000). Environmental investigations of Vibrio parahaemolyticus in oysters after outbreaks in Washington, Texas, and NewYork (1997 and 1998). Appl. Environ. Microbiol. 66, 4649-4654. doi: 10.1128/AEM.66.11.4649-4654.2000

DePaola, A., Ulaszek, J., and Kaysner, C. A. (2003). Molecular, serological, and virulence characteristics of Vibrio parahaemolyticus isolated from environmental, food, and clinical sources in North America and Asia. Appl. Environ. Microbiol. 69, 3999-4005. doi: 10.1128/AEM.69.7.3999-4005.2003

Dileep, V., Kumar, H. S., Kumar, Y., Nishibuchi, M., Karunasagar, I., and Karunasagar, I. (2003). Application of polymerase chain reaction for detection of Vibrio parahaemolyticus associated with tropical seafood and coastal environment. Lett. Appl. Microbiol. 36, 423-427. doi: 10.1046/j.1472-765X.2003. 01333.x

Di Pinto, A., Ciccarese, G., Tantillo, G., Catalano, D., and Forte, V. T. (2005). A collagenase targeted multiplex PCR assay for identification of Vibrio alginolyticus, Vibrio cholerae, and Vibrio parahaemolyticus. J. Food Prot. 68, 150-153.

Donovan, T. J., and Van Netten, P. (1995). Culture media for the isolation and enumeration of pathogenic Vibrio species in foods and environmental samples. Int. J. Food Microbiol. 26, 77-91. doi: 10.1016/0168-1605(95)00015-C

Drake, S. L., DePaola, A., and Jaykus, L. A. (2007). An overview of Vibrio vulnificus and Vibrio parahaemolyticus. Compr. Rev. Food Sci. Food Saf. 6, 120-144. doi: 10.1111/j.1541-4337.2007.00022.x

Elhadi, N., Radu, S., Chen, C. H., and Nishibuchi, M. (2004). Prevalence of potentially pathogenic Vibrio species in the seafood marketed in Malaysia. J. Food Prot. 67, 1469-1475.

Ellison, R. K., Malnati, E., DePaola, A., Bowers, J., and Rodrick, G. E. (2001). Populations of Vibrio parahaemolyticus in retail oysters from Florida using two methods. J. Food Prot. 64, 682-686.

Fakruddin, M., Mannan, K. S. B., Mazumdar, R. M., Chowdhury, A., and Hossain, M. N. (2013). Identification and characterization of microorganisms: DNA-fingerprinting methods. Songklanakarin J. Sci. Technol. 35, 397-404.

FAO/WHO. (2011). Risk assessment of Vibrio parahaemolyticus in seafood: interpretative summary and Technical report. Food and agriculture organization of the united nations/world health organization. Microbiol. Risk Assess. 16, 193.

Farmer, J. J., Janda, J. M., and Birkhead, K. (2003). "Vibrio," in Manual of Clinical Microbiology, ed. P. R. Murray (Washington, DC: ASM Press), 706-718.

Foley, S. L., Aaron, M. L., and Nayak, R. (2009). Molecular typing methodologies for microbial source tracking and epidemiological investigations of gram-negative bacterial foodborne pathogens. Infect. Genet. Evol. 9, 430-440. doi: 10.1016/j.meegid.2009.03.004
Fujino, T., Okuno, Y., Nakada, D., Aoyama, A., Mukai, T., and Ueho, T. (1953). On the bacteriological examination of shirasu food poisoning. Med. J. Osaka Univ. 4, 299-304.

Gode-Potratz, C. J., Kustusch, R. J., Breheny, P. J., Weiss, D. S., and McCarter, L. L. (2011). Surface sensing in Vibrio parahaemolyticus triggers a programme of gene expression that promotes colonization and virulence. Mol. Microbiol. 79, 240-263. doi: 10.1111/j.1365-2958.2010.07445.x

Gooch, J. A., DePaola, A., Kaysner, C. A., and Marshall, D. L. (2001). Evaluation of two direct plating methods using nonradioactive probes for enumeration of Vibrio parahaemolyticus in oysters. Appl. Environ. Microbiol. 67, 721-724. doi: 10.1128/AEM.67.2.721-724.2001

Grant, M. A., Hu, J., and Jinneman, K. C. (2006). Multiplex real-time PCR detection of heat-labile and heat-stable toxin genes in enterotoxigenic Escherichia coli. J. Food Prot. 69, 412-416.

Griffitt, K. J., Noriea, N. F. III, Johnson, C. N., and Grimes, D. J. (2011). Enumeration of Vibrio parahaemolyticus in the viable but non-culturable state using direct plate counts and recognition of individual gene fluorescence in situ hybridization. J. Microbiol. Methods 85, 114-118. doi: 10.1016/j.mimet.2011.02.006

Gutierrez West, C. K., Klein, S. L., and Lovell, C. R. (2013). High frequency of virulence factor genes tdh, trh, and th in Vibrio parahaemolyticus strains isolated from a pristine estuary. Appl. Environ. Microbiol. 79, 2247-2252. doi: 10.1128/AEM.03792-12

Hara-Kudo, Y., Nishina, T., Nakagawa, H., Konuma, H., Hasegawa, J., and Kumagai, S. (2001). Improved method for detection of Vibrio parahaemolyticus in seafood. Appl. Environ. Microbiol. 67, 5819-5823. doi: 10.1128/AEM.67.12.58195823.2001

Hara-Kudo, Y., Saito, S., Ohtsuka, K., Yamasaki, S., Yahiro, S., Nishio, T., et al. (2012). Characteristics of a sharp decrease in Vibrio parahaemolyticus infections and seafood contamination in Japan. Int. J. Food Microbiol. 157, 95-101. doi: 10.1016/j.ijfoodmicro.2012.04.019

Hara-Kudo, Y., Sugiyama, K., Nishibuchi, M., Chowdhury, A., Yatsuyanagi, J., Ohtomo, Y., et al. (2003). Prevalence of pandemic thermostable direct hemolysinproducing Vibrio parahaemolyticus $\mathrm{O} 3: \mathrm{K} 6$ in seafood and the coastal environment in Japan. Appl. Environ. Microbiol. 69, 3883-3891. doi: 10.1128/AEM.69.7.38833891.2003

He, P., Chen, Z., Luo, J., Wang, H., Yan, Y., Chen, L., et al. (2014). Multiplex real-time PCR assay for detection of pathogenic Vibrio parahaemolyticus strains. Mol. Cell. Probes 28, 246-250 doi: 10.1016/j.mcp.2014.06.001

Hervio-Heath, D., Colwell, R. R., Derrien, A., Robert-Pillot, A., Fournier, J, M., and Pommepuy, M. (2002). Occurrence of pathogenic Vibrio in coastal areas of France. J. Appl. Microbiol. 92, 1123-1135. doi: 10.1046/j.1365-2672.2002.01663.x

Hurley, C., Quirke, A., Reen, F., and Boyd, E. (2006). Four genomic islands that mark post-1995 pandemic Vibrio parahaemolyticus isolates. BMC Genomics 7:104. doi: 10.1186/1471-2164-7-104

Igbinosa, E. O., and Okoh, A. I. (2008). Emerging Vibrio species: an unending threat to public health in developing countries. Res. Microbiol. 159, 495-506. doi: 10.1016/j.resmic.2008.07.001

Iwamoto, M., Ayers, T., Mahon, B. E., and Swerdlow, D. L. (2010). Epidemiology of seafood-associated infections in the United States. Clin. Microbiol. Rev. 23, 399-411. doi: 10.1128/CMR.00059-09

Izore, T., Job, V., and Dessen, A. (2011). Biogenesis, regulation, and targeting of the type III secretion system. Structure 13, 603-612. doi: 10.1016/j.str.2011. 03.015

Izutsu, K., Kurokawa, K., Tashiro, K., Kuhara, S., Hayashi, T., Honda, T., et al. (2008). Comparative genomic analysis using microarray demonstrates a strong correlation between the presence of the 80 -kilo base pathogenicity island and pathogenicity in Kanagawa phenomenon-positive Vibrio parahaemolyticus strains. Infect. Immun. 76, 1016-1023. doi: 10.1128/IAI.01535-07

Jacxsens, L., Kasuga, J., Luning, P. A., Van der Spiegel, M., Devlieghere, F., and Uyttendaele, M. (2009). A microbial assessment scheme to measure microbial performance of food safety management systems. Int. J. Food Microbiol. 134, 113-125. doi: 10.1016/j.ijfoodmicro.2009.02.018

Jones, J. L., Ludeke, C. H. M., Bowers, J. C., Garrett, N., Fischer, M., Parsons, M. B., et al. (2012). Biochemical, serological, and virulence characterization of clinical and oyster Vibrio parahaemolyticus isolates. J. Clin. Microbiol. 50, 2343-2352. doi: 10.1128/JCM.00196-12

Jiang, W. P. (1991). A study on diarrhoea disease caused by Vibrionaceae along coast the east of Zhejiang Province. Zhonghua Yu Fang Yi Xue Za Zhi 25, 335-337. 
Kanungo, S., Sur, D., Ali, M., You, Y. A., Pal, D., Manna, B., et al. (2012). Clinical, epidemiological, and spatial characteristics of Vibrio parahaemolyticus diarrhea and cholera in the urban slums of Kolkata, India. BMC Pub. Health 12:830. doi: 10.1186/1471-2458-12-830

Kaufman, G. E., Blackstone, G. M., Vickery, M. C. L., Bej, A. K., Bowers, J., Bowen, M. D., et al. (2004). Real time PCR quantification of Vibrio parahaemolyticus in oysters using an alternative matrix. J. Food Prot. 67, 2424-2429.

Kaysner, C. A., Abeyta, C. Jr., Stott, R. F., Lilja, J. L., and Wekell, M. M. (1990). Incidence of urea-hydrolyzing Vibrio parahaemolyticus in Willapa Bay, Washington. Appl. Environ. Microbiol. 56, 904-907.

Kaysner, C. A., and DePaola, A. (2001). "Vibrio," in Compendium of Methods for the Microbiological Examination of Foods, 4th Edn, eds F. P. Downes and K. Ito (Washington, DC: American Public Health Association), 405-420.

Kaysner, C. A., and DePaola, A. (2004). Vibrio. Bacteriological Analytical Manual, Chapter 9. Arlington, VA: U.S. Food and Drug Administration.

Kim, Y. B., Okuda, J., Matsumoto, C., Takahashi, N., Hashimoto, S., and Nishibuchi, M. (1999). Identification of Vibrio parahaemolyticus strains at the species level by PCR targeted to the toxR gene. J. Clin. Microbiol. 37, 1173-1177.

Kobayashi, T., Enomoto, S., Sakazaki, R., and Kuwahara, S. (1963). A new selective isolation medium for the Vibrio group on a modified Nakanishi's medium (TCBS agar medium). Nippon Saikingaku Zasshi 18, 387-392. doi: 10.3412/jsb. 18.387

Kodama, T., Rokuda, M., Park, K.-S., Cantarelli, V. V., Matsuda, S., Iida, T., et al. (2007). Identification and characterization of VopT, a novel ADP- ribosyltransferase effector protein secreted via the Vibrio parahaemolyticus type III secretion system 2. Cell. Microbiol. 9, 2598-2609. doi: 10.1111/j.1462-5822.2007.00980.x

Krachler, A. M., Ham, H., and Orth, K. (2011). Outer membrane adhesion factor multivalent adhesion molecule 7 initiates host cell binding during infection by Gram-negative pathogens. Proc. Natl. Acad. Sci. U.S.A. 108, 11614-11619. doi: $10.1073 /$ pnas. 1102360108

Krachler, A. M., Ham, H., and Orth, K. (2012). Turnabout is fair play: use of the bacterial multivalent adhesion molecule 7 as an antimicrobial agent. Virulence 3 , 68-71. doi: 10.4161/viru.3.1.18172

Krachler, A. M., and Orth, K. (2011). Functional characterization of the interaction between bacterial adhesin multivalent adhesion molecule 7 (MAM7) protein and its host cell ligands. J. Biol. Chem. 286, 38939-38947. doi 10.1074/jbc.M111.291377

Kubota, K., Kasuga, F., Iwasaki, E., Inagaki, S., Sakurai, Y., Komatsu, M., et al. (2011). Estimating the burden of acute gastroenteritis and foodborne illness caused by Campylobacter, Salmonella, and Vibrio parahaemolyticus by using populationbased telephone survey data, Miyagi Prefecture, Japan, 2005 to 2006. J. Food Prot. 74, 1592-1598. doi: 10.4315/0362-028X.JFP-10-387

Lee, C., Chen, L. H., Liu, M. L., and Su, Y. C. (1992). Use of an oligonucleotide probe to detect Vibrio parahaemolyticus in artificially contaminated oysters. Appl. Environ. Microbiol. 58, 3419-3422.

Lee, J., Jung, D., Eom, S., Oh, S., Kim, Y., Kwak, H., et al. (2008). Occurrence of Vibrio parahaemolyticus in oysters from Korean retail outlets. Food Control 19, 990-994. doi: 10.1016/j.foodcont.2007.10.006

Li, Y., Xie, X., Shi, X., Lin, Y., Qiu, Y., Mou, J., et al. (2014). Vibrio parahaemolyticus, Southern Coastal Region of China, 2007-2012. Emerg. Infect. Dis. 20, 685-688. doi: 10.3201/eid2004.130744

Liu, X., Chen, Y., Wang, X., and Ji, R. (2004). Foodborne disease outbreaks in China from 1992 to 2001, National foodborne disease surveillance system. J. Hyg. Res. $33,725-727$.

Lozano-Leon, A., Torres, J., Osorio, C. R., and Mart $\iota$ nez-Urtaza, J. (2003). Identification of tdh-positive Vibrio parahaemolyticus from an outbreak associated with raw oyster consumption in Spain. FEMS Microbiol. Lett. 226, 281-284. doi: 10.1016/S0378-1097(03)00604-9

Luan, X., Chen, J., Liu, Y., Li, Y., Jia, J., Liu, R., et al. (2008). Rapid quantitative detection of Vibrio parahaemolyticus in seafood by MPN-PCR. Curr. Microbiol. 57, 218-221. doi: 10.1007/s00284-008-9177-x

Makino, K., Oshima, K., Kurokawa, K., Yokoyama, K., Uda, T., Tagomori, K., et al. (2003). Genome sequence of Vibrio parahaemolyticus: a pathogenic mechanism distinct from that of Vibrio cholerae. Lancet 361, 743-749. doi: 10.1016/S01406736(03)12659-1

Marlovits, T. C., and Stebbins, C. E. (2010). Type III secretion systems shape up as they ship out. Curr. Opin. Microbiol. 13, 47-52. doi: 10.1016/j.mib.2009. 11.001
Martin, B., Jofre, A., Garriga, M., Hugas, M., and Aymerich, T. (2004). Quantification of Listeria monocytogenes in fermented sausages by MPN-PCR method. Lett. Appl. Microbiol. 39, 290-295. doi: 10.1111/j.1472-765X.2004.01580.x

Martinez-Urtaza, J., Simental, L., Velasco, D., DePaola, A., Ishibashi, M., Nakaguchi, Y., et al. (2005). Pandemic Vibrio parahaemolyticus O3:K6, Europe. Emerg. Infect. Dis. J. 11, 1319-1320. doi: 10.3201/eid1108.050322

Matsumoto, C., Okuda, J., Ishibashi, M., Iwanaga, M., Garg, P., Ramamurthy, T., et al. (2000). Pandemic spread of an O3:K6 clone of Vibrio parahaemolyticus \& emergence of related strains evidenced by Arbitrarily Primed PCR \& toxRS sequence analysis. J. Clin. Microbiol. 38, 578-585.

McKillip, J. L., and Drake, M. (2000). Molecular beacon polymerase chain reaction detection of Escherichia coli 0157:H7 in milk. J. Food Prot. 63, 855-859.

McLaughlin, J. B., DePaola, A., Bopp, C. A., Martinek, K. A., and Napol, N. P. (2005). Outbreak of Vibrio parahaemolyticus gastroenteritis associated with Alaskan oysters. New Engl. J. Med. 353, 1463-1470. doi: 10.1056/ NEJMoa051594

Miwa, N., Kashiwagi, M., Kawamori, F., Masuda, T., Sano, Y., Hiroi, M., et al. (2006). Levels of Vibrio parahaemolyticus and thermostable direct hemolysin gene-positive organisms in retail seafood determined by the most probable number-polymerase chain reaction (MPN-PCR) method. Medline 47, 4-45.

Miwa, N., Nishio, T., Arita, Y., Kawamori, F., Masuda, T., and Akiyama, M. (2003). Evaluation of MPN method combined with PCR procedure for detection and enumeration of Virbio parahaemolyticus in seafood. J. Food Hyg. Soc. Japan 44, 289-293. doi: 10.3358/shokueishi.44.289

Miwatani, T., and Takeda, Y. (1976). Vibrio parahaemolyticus: A Causative Bacterium of Food Poisoning. (Tokyo: Saikon Publishing Co. Ltd), 1-5.

Miyasaka, J., Yahiro, S., Arahira, Y., Tokunaga, H., Katsuki, K., and HaraKudo, Y. (2006). Isolation of Vibrio parahaemolyticus and Vibrio vulnificus from wild aquatic birds in Japan. Epidemiol. Infect. 134, 780-785. doi: 10.1017/S0950268805005674

Molenda, J. R., Johnson, W. G., Fishbein, M., Wentz, B., Mehlman, I. J., and Dadisman, T. A. Jr. (1972). Vibrio parahaemolyticus gastroenteritis in Maryland: laboratory aspects. Appl. Microbiol. 24, 444-448.

Mrityunjoy, A., Kaniz, F., Fahmida, J., Shanzida, J. S., Md. Aftab, U., and Rashed, N. (2013). Prevalence of Vibrio cholerae in different food samples in the city of Dhaka, Bangladesh. Int. Food Res. J. 20, 1017-1022.

Nair, G. B., Ramamurthy, T., Bhattacharya, S. K., Dutta, B., Takeda, Y., and Sack, D. A. (2007). Global dissemination of Vibrio parahaemolyticus serotype O3:K6 and its serovariants. Clin. Microbiol. Rev. 20, 39-48. doi: 10.1128/CMR.00025-06

Namgoong, S., Boczkowska, M., Glista, M. J., Winkelman, J. D., Rebowski, G., Kovar, D. R., et al. (2011). Mechanism of actin filament nucleation by Vibrio VopL and implications for tandem W domain nucleation. Nat. Struct. Mol. Biol. 18, 1060-1067. doi: 10.1038/nsmb.2109

Nasu, H., Iida, T., Sugahara, T., Yamaichi, Y., Park, K.-S., Yokoyama, K., et al. (2000). A filamentous phage associated with recent pandemic Vibrio parahaemolyticus O3:K6 strains. J. Clin. Microbiol. 38, 2156-2161. doi: 10.3201/eid0703. 010325

Nelapati, S., Nelapati, K., and Chinnam, B. K. (2012). Vibrio parahaemolyticus-An emerging foodborne pathogen-A Review. Vet. World 5, 48-62. doi: 10.5455/vetworld.2012.48-63

Nemoto, J., Ikedo, M., Kojima, T., Momoda, T., Konuma, H., and Hara-Kudo, Y. (2011). Development and evaluation of a loop mediated isothermal amplification assay for rapid and sensitive detection of Vibrio parahaemolyticus. J. Food Prot. 74, 1462-1467. doi: 10.4315/0362-028X.JFP-10-519

Nemoto, J., Sugawara, C., Akahane, K., Hashimoto, K., Kojima, T., Ikedo, M., et al. (2009). Rapid and specific detection of the thermostable direct hemolysin gene in Vibrio parahaemolyticus by loop-mediated isothermal amplification. J. Food Prot. 72, 748-754.

Newton, A., Kendall, M., Vugia, D. J., Henao, O. L., and Mahon, B. E. (2012). Increasing rates of vibriosis in the United States, 1996-2010: review of surveillance data from 2 systems. Clin. Infect. Dis. 54, S391-S395. doi: 10.1093/cid/cis243

Nishibuchi, M. (2006). The biology of Vibrios: molecular identification. Am. Soc. Microbiol. 4, 44-64.

Nishibuchi, M., and Kaper, J. B. (1995). Thermostable direct hemolysin gene of Vibrio parahaemolyticus: a virulence gene acquired by a marine bacterium. Infect. Immun. 63, 2093-2099.

Nishibuchi, M., Taniguchi, T., Misawa, T., Khaeomanee-Iam, V., Honda, T., and Miwatano, T. (1989). Cloning and nucleotide sequence of the gene (trh) 
encoding the nemolysin related to the thermostable direct hemolysin of Vibrio parahaemolyticus. Infect. Immun. 57, 2677-2691.

Nishioka, T., Kamruzzaman, M., Nishibuchi, M., and Satta, Y. (2008). On the origin and function of an insertion element VPaI-1 specific to post-1995 pandemic Vibrio parahaemolyticus strains. Genes Genet. Syst. 83, 101-110. doi: 10.1266/ggs.83.101

Nordstrom, J. L., and DePaola, A. (2003). Improved recovery of pathogenic Vibrio parahaemolyticus from oysters using colony hybridization following enrichment. J. Microbiol. Methods 52, 273-277. doi: 10.1016/S0167-7012(02)00188-4

Nordstrom, J. L., Vickery, M. C., Blackstone, G. M., Murray, S. L., and DePaola, A. (2007). Development of a multiplex real-time PCR assay with an internal amplification control for the detection of total and pathogenic Vibrio parahaemolyticus bacteria in oysters. Appl. Environ. Microbiol. 73, 5840-5847. doi: 10.1128/AEM.00460-07

Notomi, T., Okayama, H., Masubuchi, H., Yonekawa, T., Watanabe, K., Amino, N., et al. (2000). Loop mediated isothermal amplification of DNA. Nucleic Acids Res. 20, e63. doi: 10.1093/nar/28.12.e63

Oakey, H. J., Gibson, L. F., and George, A. M. (1998). Co-migration of RAPD-PCR amplicos from Aeromonas hydrophila. FEMS Microbiol. Lett. 164, 35-38. doi: 10.1111/j.1574-6968.1998.tb13064.x

Ono, T., Park, K. S., Ueta, M., Iida, T., and Honda, T. (2006). Identification of proteins secreted via Vibrio parahaemolyticus type III secretion system 1. Infect. Immun. 74, 1032-1042. doi: 10.1128/IAI.74.2.1032-1042.2006

Papa, F. (1980). Study \& significance of Vibrio parahaemolyticus in the coastal waters of Guadeloupe. Bull. Soc. Pathol. Exot. Filiales 73, 380-383.

Paranjpye, R., Hamel, O. S., Stojanovski, A., and Liermann, M. (2012). Genetic diversity of clinical and environmental Vibrio parahaemolyticus strains from the Pacific Northwest. Appl. Environ. Microbiol. 78, 8631-8638. doi: 10.1128/AEM 01531-12

Park, K. S., Ono, T., Rokuda, M., Jang, M. H., Okada, K., Iida, T., et al. (2004). Functional characterization of two type III secretion systems of Vibrio parahaemolyticus. Infect. Immun. 72, 6659-6665. doi: 10.1128/IAI.72.11.66596665.2004

Paydar, M., Teh, C. S. J., and Thong, K. L. (2013). Prevalence and characterisation of potentially virulent Vibrio parahaemolyticus in seafood in Malaysia using conventional methods, PCR and REP-PCR. Food Control 32, 13-18. doi: 10.1016/j.foodcont.2012.11.034

Pazhani, G. P., Bhowmik, S. K., Ghosh, S., Guin, S., Dutta, S., Rajendran, K., et al. (2014). Trends in the epidemiology of pandemic and non-pandemic strains of Vibrio parahaemolyticus isolated from diarrheal patients in Kolkata, India. PLoS Negl. Trop. Dis. 8:2815. doi: 10.1371/journal.pntd.0002815

Peng, F. M., Jiang, D. Y., Ruan, H. H., Liu, H. Q., and Zhou, L. P. (2010). Pathogenic investigation on a food poisoning induced by Vibrio parahaemolyticus. Prev. Med. Tribune 16, 746-747.

Pinto, D. A., Terio, V., Novello, L., and Tantillo, G. (2011). Comparison between thiosulphate-citrate-bile salt sucrose (TCBS) agar and CHROMagar Vibrio for isolating Vibrio parahaemolyticus. Food Control 22, 124-127. doi: 10.1016/j.foodcont.2010.06.013

Qadri, F., Chowdhury, N. R., Takeda, Y., and Nair, G. B. (2005). Vibrio parahaemolyticus - seafood safety and associations with higher organisms. Oceans Health Pathog. Mar. Environ. 277-295. doi: 10.1007/0-387-23709-7_11

Raghunath, P., Karunasagar, I., and Karunasagar, I. (2009). Improved isolation and detection of pathogenic Vibrio parahaemolyticus from seafood using a new enrichment broth. Int. J. Food Microbiol. 129, 200-203. doi: 10.1016/j.ijfoodmicro.2008.11.026

Reyhanath, P. V., and Kutty, R. (2014). Incidence of multidrug resistant Vibrio parahaemolyticus isolated from Ponnani, South India. Iranian J. Microbiol. 6 , 60-67.

Robert-Pillot, A., Copin, S., Gay, M., Malle, P., and Quilici, M. L. (2010). Total and pathogenic Vibrio parahaemolyticus in shrimp: fast and reliable quantification by real time PCR. Int. J. Food Microbiol. 143, 190-197. doi: 10.1016/j.ijfoodmicro.2010.08.016

Robert-Pillot, A., Guenole, A., Lesne, J., Delesmont, R., Fournier, J. M., and Quilici, M. L. (2004). Occurrence of the tdh and trh genes in Vibrio parahaemolyticus isolates from waters and raw shellfish collected in two French coastal areas and from seafood imported into France. Int. J. Food Microbiol. 91, 319-325. doi: 10.1016/j.ijfoodmicro.2003.07.006
Salomon, D., Gonzalez, H., Updegraff, B. L., and Orth, K. (2013). Vibrio parahaemolyticus type VI secretion system 1 is activated in marine conditions to target bacteria, and is differentially regulated from system 2. PLOS ONE 8:61086. doi: 10.1371/journal.pone.0061086

Sawabe, T., Yoshizawa, A., Kawanishi, Y., Komatsu-Takeda, E., Nakagawa, S., Sawabe, T., et al. (2009). Multi-probe-fluorescence in situ hybridization for the rapid enumeration of viable Vibrio parahaemolyticus. Microbes Environ. 24, 259-264. doi: 10.1264/jsme2.ME09129

Sreelatha, A., Bennett, T. L., Zheng, H., Jiang, Q.-X., Orth, K., and Starai, V. J. (2013). Vibrio effector protein, VopQ, forms a lysosomal gated channel that disrupts host ion homeostasis and autophagic flux. Proc. Natl. Acad. Sci. U.S.A. 110, 11559-11564. doi: 10.1073/pnas.1307032110

Suffredini, E., Cozzi, L., Ciccaglioni, G., and Croci, L. (2014a). Development of a colony hybridization method for the enumeration of total and potentially enteropathogenic Vibrio parahaemolyticus in shellfish. Int. J. Food Microbiol. 186, 22-31. doi: 10.1016/j.ijfoodmicro.2014.06.009

Suffredini, E., Mioni, R., Mazzette, R., Bordin, P., Serratore, P., Fois, F., et al. (2014b). Detection and quantification of Vibrio parahaemolyticus in shellfish from Italian production areas. Int. J. Food Microbiol. 184, 14-20. doi: 10.1016/j.ijfoodmicro.2014.04.016

Su, C. Y., and Liu, C. (2007). Vibrio parahaemolyticus: a concern of seafood safety. Res. Microbiol. Elsevier. 24, 549-558.

Sudha, S., Mridula, C., Silvester, R., and Hatha, A. A. M. (2014). Prevalence and antibiotic resistance of pathogenic Vibrios in shellfishes from Cochin market. Indian J. Geo Mar. Sci. 43, 815-824.

Sujeewa, A. K. W., Norrakiah, A. S., and Laina, M. (2009). Prevalence of toxic genes of Vibrio parahaemolyticus in shrimps (Penaeus monodon) and culture environment. Int. Food Res. J. 16, 89-95.

Sun, X., Xu, Q., Pan, Y., Lan, W., and Vivian, C. H. (2011). A loop-mediated isothermal amplification method for rapid detection of Vibrio parahaemolyticus in seafood. Ann. Microbiol. 62, 263-271. doi: 10.1007/s13213-011-0255-0

Sutton, S. (2010). The most probable number method and its uses in enumeration, qualification and validation. Microbiol. Top. J. Validation Tech. 35-38.

Thompson, F. L., Iida, T., and Swings, J. (2004). Biodiversity of Vibrios. Microbiol. Mol. Biol. Rev. 68, 403-431. doi: 10.1128/MMBR.68.3.403-431.2004

Trosky, J. E., Mukherjee, S., Burdette, D. L., Roberts, M., McCarter, L., Siegel, R. M., et al. (2004). Inhibition of MAPK signalling pathways by VopA from Vibrio parahaemolyticus. J. Biol. Chem. 279, 51953-51957. doi: 10.1074/jbc.M407001200

Tunung, R., Ghazali, F. M., Noranizan, M. A., Haresh, K. K., Lesley, M. B., Nakaguchi, Y., et al. (2011). Rapid detection and enumeration of pathogenic Vibrio parahaemolyticus in raw vegetables from retail outlets. Int. Food Res. J. 18, 67-78.

Tunung, R., Margaret, S. P., Jeyaletchumi, P., Chai, L. C., Zainazor, T. C., Ghazali, F. M., et al. (2010). Prevalence and quantification of Vibrio in raw salad vegetables at retail level. J. Microbiol. Biotech. 20, 391-396.

Velazquez-Roman, J., Leon-Sicairos, N., Flores-Villasenor, H., Villafana-Rauda, S., and Canizalez-Roman, A. (2012). Association of pandemic Vibrio parahaemolyticus O3: K6 present in the coastal environment of Northwest Mexico with cases of recurrent diarrhea between 2004 and 2010. Appl. Environ. Microbiol. 78, 1794-1803. doi: 10.1128/AEM.06953-11

Velusamy, V., Arshak, K., Korostynska, O., Oliwa, K., and Adley, C. (2010). An Overview of foodborne pathogen detection: in the perspective of biosensors. Biotech. Adv. 28, 232-254. doi: 10.1016/j.biotechadv.2009.12.004

Venkateswaran, K., Dohmoto, N., and Harayama, S. (1998). Cloning and nucleotide sequence of the gene detection of Vibrio parahaemolyticus and its application detection of this pathogen in shrimp. Appl. Enrion. Microbiol. 64, 681-687.

Vesa, M., Seppo, N., Seppo, K., Tuula, P., and Kristina, L. (1997). MPN-PCRquantification method for staphylococcal enterotoxin $\mathrm{cl}$ gene from fresh cheese. Int J. Food Microbiol. 36, 135-143. doi: 10.1016/S0168-1605(97)01243-9

Vimala, B., Lin, T. K., and Chong, V. C. (2010). Isolation, detection and genomic differentiation of Vibrio cholerae and Vibrio parahaemolyticus in Bachok, Kelantan. Malays J. Sci. 29, 1-10.

Vongxay, K., Wang, S., Zhang, X., Wu, B., Hu, H., Pan, Z., et al. (2008). Pathogenetic characterization of Vibrio parahaemolyticus isolates from clinical and seafood sources. Int. J. Food Microbiol. 126, 71-75. doi: 10.1016/j.ijfoodmicro.2008.04.032 Vuddhakul, V., Chowdhury, A., Laohaprertthisan, V., Pungrasamee, P., Patararungrong, N., and Thianmontri, P. (2000). Isolation of a pandemic O3:K6 clone of a Vibrio parahaemolyticus strain from environmental and clinical sources in 
Thailand. Appl. Environ. Microbiol. 66, 2685-2689. doi: 10.1128/AEM.66.6.26852689.2000

Ward, L. N., and Bej, A. K. (2006). Detection of Vibrio parahaemolyticus in shellfish by use of multiplexed real-time PCR with TaqMan fluorescent probes. Appl. Environ. Microbiol. 72, 2031-2042. doi: 10.1128/AEM.72.3.2031-2042.2006

Wei, S., Zhao, H., Xian, Y., Hussain, M. A., and Wu, X. (2014). Multiplex PCR assays for the detection of Vibrio alginolyticus, Vibrio parahaemolyticus, Vibrio vulnificus and Vibrio cholerae with an internal amplification control. Diagn. Microbiol. Infect. Dis. 79, 115-118. doi: 10.1016/j.diagmicrobio.2014.03.012

Wilson, B. A., and Salyers, A. A. (2003). Is the evolution of bacterial pathogens an out-of-body experience? Trends Microbiol. 11, 347-350. doi: 10.1016/S0966842X(03)00179-3

Wong, H. C., and Lin, C. H. (2001). Evaluation of typing of Vibrio parahaemolyticus by three PCR methods using specific primers. J. Clin. Microbiol. 39, 4233-4240. doi: 10.1128/JCM.39.12.4233-4240.2001

Wong, H. C., Liu, S. H., Wang, T. K., Lee, C. L., Chiou, C. S., and Liu, D. P. (2000a). Characteristics of Vibrio parahaemolyticus O3:K6 from Asia. Appl. Environ. Microbiol. 66, 3981-3986. doi: 10.1128/AEM.66.9.3981-3986.2000

Wong, H. C., Liu, S. H., Ku, L. W., Lee, I. Y., Wang, T. K., Lee, Y. S., et al. (2000b). Characterization of Vibrio parahaemolyticus isolates obtained from foodborne illness outbreaks during 1992 through 1995 in Taiwan. J. Food Prot. 63, 900-906.

Wu, L., Zhang, J., and Ni, Y. (1998). A study on the distribution \& etiology of pathogenic Vibrio in the 5 coastal provinces of China. Zhonghua Liu Xing Bing Xue Za Zhi 19, 301-303.

Xu, X., Wu, Q., Zhang, J., Cheng, J., Zhang, S., and Wu, K. (2014). Prevalence, pathogenicity, and serotypes of Vibrio parahaemolyticus in shrimp from Chinese retail markets. Food Control 46, 81-85. doi: 10.1016/j.foodcont.2014.04.042

Yamazaki, W., Ishibashi, M., Kawahara, R., and Inoue, K. (2008). Development of a loop mediated isothermal amplification assay for sensitive and rapid detection of Vibrio parahaemolyticus. BMC Microbiol. 8:163. doi: 10.1186/1471-2180-8-163

Yamazaki, W., Kumeda, Y., Misawa, N., Nakaguchi, Y., and Nishibuchi, M. (2010). Development of a loop mediated isothermal amplification assay for sensitive and rapid detection of the tdh and trh genes of Vibrio parahaemolyticus and related Vibrio species. Appl. Environ. Microbiol. 76, 820-828. doi: 10.1128/AEM.02284-09

Yano, Y., Hamano, K., Satomi, M., Tsutsui, I., Ban, M., and Aue-Umneoy, D. (2014). Prevalence and antimicrobial susceptibility of Vibrio species related to food safety isolated from shrimp cultured at inland ponds in Thailand. Food Control 38, 30-36. doi: 10.1016/j.foodcont.2013.09.019

Yeung, P. M., Hayes, M. C., DePaola, A., Kaysner, C. A., Kornstein, L., and Boor, K. J. (2002). Comparative phenotypic, molecular, and virulence characterization of Vibrio parahaemolyticus O3: K6 isolates. Appl. Environ. Microbiol. 68, 2901-2909. doi: 10.1128/AEM.68.6.2901-2909.2002

Yi, M. Y., Ling, L., Neogi, S. B., Fan, Y., Tang, D. Y., Yamasaki, S., et al. (2014). Real time loop-mediated isothermal amplification using a portable fluorescence scanner for rapid and simple detection of Vibrio parahaemolyticus. Food Control 41, 91-95. doi: 10.1016/j.foodcont.2014.01.005
Yu, W. T., Jong, K. J., Lin, Y. R., Tsai, S. E., Tey, Y. H., and Wong, H. C. (2013). Prevalence of Vibrio parahaemolyticus in oyster and clam culturing environments in Taiwan. Int. J. Food Microbiol. 160, 185-192. doi: 10.1016/j.ijfoodmicro.2012.11.002

Yu, Y., Yang, H., Li, J., Zhang, P., Wu, B., Zhu, B., et al. (2012). Putative type VI secretion systems of Vibrio parahaemolyticus contribute to adhesion to cultured cell monolayers. Arch. Microbiol. 194, 827-835. doi: 10.1007/s00203-0120816-z

Zarei, M., Borujeni, M. P., Jamnejad, A., and Khezrzadeh, M. (2012). Seasonal prevalence of Vibrio species in retail shrimps with an emphasis on Vibrio parahaemolyticus. Food Control 25, 107-109. doi: 10.1016/j.foodcont.2011.10.024

Zeng, J., Wei, H., Zhang, L., Liu, X., Zhang, H., Cheng, J., et al. (2014). Rapid detection of Vibrio parahaemolyticus in raw oysters using immunomagnetic separation combined with loop-mediated isothermal amplification. Int. J. Food Microbiol. 174, 123-128. doi: 10.1016/j.ijfoodmicro.2014.01.004

Zhang, L., Krachler, A. M., Broberg, C. A., Li, Y., Mirzaei, H., Gilpin, C. J., et al. (2012). Type III effector VopC mediates invasion for Vibrio species. Cell Rep. 1, 453-460. doi: 10.1016/j.celrep.2012.04.004

Zhang, L., and Orth, K. (2013). Virulence determinants for Vibrio parahaemolyticus infection. Curr. Opin. Microbiol. 16, 70-77. doi: 10.1016/j.mib.2013.02.002

Zheng, Y., Wu, Q., Wu, K., Zhang, J., Guo, W., and Wu, K. (2014). Virulenceassociated gene detection and ERIC-PCR typing of Campylobacter jejuni strains isolated from foods in four Southern Chinese provinces. Acta Microbiol. Sinica 54, 14-23.

Zhou, X., Konkel, M. E., and Call, D. R. (2010). Regulation of type III secretion system 1 gene expression in Vibrio parahaemolyticus is dependent on interactions between ExsA, ExsC, and ExsD. Virulence 1, 260-272. doi: 10.4161/viru.1.4. 12318

Conflict of Interest Statement: The authors declare that the research was conducted in the absence of any commercial or financial relationships that could be construed as a potential conflict of interest.

Received: 03 October 2014; accepted: 27 November 2014; published online: 11 December 2014.

Citation: Letchumanan V, Chan K-G and Lee L-H (2014) Vibrio parahaemolyticus: a review on the pathogenesis, prevalence, and advance molecular identification techniques. Front. Microbiol. 5:705. doi: 10.3389/fmicb.2014.00705

This article was submitted to Food Microbiology, a section of the journal Frontiers in Microbiology.

Copyright (c) 2014 Letchumanan, Chan and Lee. This is an open-access article distributed under the terms of the Creative Commons Attribution License (CC BY). The use, distribution or reproduction in other forums is permitted, provided the original author(s) or licensor are credited and that the original publication in this journal is cited, in accordance with accepted academic practice. No use, distribution or reproduction is permitted which does not comply with these terms. 